Philosophy and Progress: Vols. LVII-LVIII, January-June, July-December, 2015 ISSN 1607-2278 (Print), DOI : http://dx.doi.org/10.3329/pp.v57il-2.31202

\section{ISLAMIC VALUES AND ENVIRONMENTAL DISQUIET}

\section{Ichhimuddin Sarkar}

Various scientific inventions and discoveries, in addition to the use of atomic energy for security purposes, are intended to ensure smooth and comfortable human life. But simultaneously the effects of such a mechanism have affected the environment by endangering almost all species of the earth. This has led many scholars to think over environmental pollution from different perspectives. In such a background, the terms like environmentalism and environmental ethics have gained popularity in some of the writings and researches of our time. It is noteworthy that, recent scholars are considering problems caused by industries as well as various types of wars. While efforts are present to resist pollution, attempts have also been made to look into the religious texts and their warnings to

* Professor, Department of History, University of North Bengal, India, E-mail : isarkar_nbu@yahoo.com mankind about the consequences of polluted environment. This paper is intended to highlight environmental disquiet vis-à-vis Islamic religious texts i.e. The Quran and The Hadith (sayings of Prophet Muhammed, S.A.W).The fact remains that, most worldly religions have admitted the relation between 'man and environment'. In some of the religions, environment has been utilised to cope with the daily needs of human beings while others have cautioned men to take care of its vulnerability and protection.

In the light of historical experience, the relationship between man and environment may be examined from two dimensions - (i) theory of lordship, wherein man is supposed to be the Lord of nature and environment and he can utilise nature as well as dominate it according to his will; and (ii) theory of stewardship, wherein nature can strengthen the existence of human species. The underlying characteristic of the theory of lordship is that it aims at legitimizing the command of man over nature or environment. However, the theory of stewardship implies the required ethics of humans to protect nature and environment from crisis.

In the Islamic ethics, the inter-relationship of man and nature is based on certain moral values. Every discussion on ethics in Islam is supposed to originate from Tawhid (Unity of God) as it is the sine qua non of Islamic faith. In Islam, ethics is said to be inseparable from religion and it is built entirely upon it (Al Faruki, 1979, p. 25) Not only Tawhid but a principle concerning metaphysics and theology gives Islam its unique profile. The unitary principle of Tawhid dictates the acceptance of God as the only source of all values who is certainly the final end to everything. This is an axiom which finds its justification when 'The Holy Quran', in its Sura Araf, mentions "work not confusion in the earth after the fair 
ordering (thereof) and call on him in fear and hope. Lo! The mercy of Allah is nigh unto the good”. (7:56; Pickthall, p. 146) It shows that the Almighty warns man that everything in the natural world acts according to the system of balance and perfection and above all, purity. 'The Holy Quran' emphasizes that, the earth and all its natural and living components are perfect and healthy; it is man who plays with its perfection and destroys it. A survey of the natural world and its components along with the relationship and changes that occur in it will show the wisdom, accuracy and perfection that surrounds it. For, in this world there is nothing created uselessly or to hurt anyone (and even if it does), it is rather a relative one due to the fact that man was prohibited from practising it in the first place.

Surely, our present world has been witnessing the most dreadful kind of corruption on environment as well as destruction which man was expected to prevent. The Almighty has created man as one of the earthly components and commands him to protect it. He emphasizes this responsibility, reflected in one of the Suras of The Holy Quran, Surah Naml, wherein it is elaborated as "And thou seest the hills; thou deemest solid flying with the flight of clouds; the doing of Allah who perfecteth all things. Lo! He is informed of what ye do.” (27:88; Pickthall, p. 376)

Protection of the natural and social environment is one of the significant goals of Islam for the sake of human survival and simultaneously its concern is connected with the wellbeing of the life system in this earth. So, Islam as a religion lays emphasis on the well-being and co-existence of man and his surroundings. It has also chosen certain steps for protecting health and environment. This is based on the principle that whatever the Almighty Lord creates is perfect, accurate and is not in vain. But experiences show that in various historical circumstances man has become aggressive and adamant inviting destruction of not only the human society but also the ecology. In this regard 'The Holy Quran' holds men responsible for environmental pollution by saying in Sura ArRum that "corruption has appeared in the land and the sea because (the evil) which men's hands have done, that He may make them taste a part of that which they have done, in order that they may return.” (30:41; Pickthall, p. 400) Again in the 'Quran' (Sura Ma'idah) we see an address from the Almighty that "Allah would not place a burden on you but He would purify you and would perfect His grace upon you, that ye may give thanks.” (5:6; Pickthall, p. 100) From this it is clear that, purity and the protection of environment from pollution is regarded as Allah's blessing and this should be appreciated. Hence, we can understand that the blessings of health, good life and wealth, etc. may be incomplete without the cleanliness of the environment and its protection against pollution and destruction, because if it is otherwise, it will continue to be under the danger and threat of destruction. Prophet Muhammed (S.A.W.) while talking on health, environment, sanitation and purity of man's surroundings says: "Surely, your body has a right over you." (Jawziyya, 1983, p. 78) He was even particular about cleanliness of human habitation and while emphasizing the purity of nature He used to say "Sweep your courtyard and don’t be like the Jews.” (Kulayni, p. 78)

It may be noted that, Prophet Muhammed (S.A.W.) was quite concerned about dirtiness and it may be substantiated by the statement of Jabir bin Abdullah Ansari, one of the followers of the Prophet, who on an occasion stated that 'One day the Holy Prophet (S.A.W.) came to us and he saw a man in a shaggy condition; his hair remained uncombed. Then He said, 'Does not this one have what his hair needs?'” (Sunan 
Abu-Dawood, v. 4, p. 51) It is also reported that, once the Prophet found a man with dirty clothes and $\mathrm{He}$ is said to have reacted in the words like "Does not this one (i.e. the man concerned) have water to wash his clothes?" (Ibid.) In this way, it is clear how Islam in its text book i.e. 'Al-Quran' and the Prophet (S.A.W.) have laid stress that Allah wants His best creature i.e. man, a pleasant and pure life and to live and ensure an unpolluted environment. The Holy Prophet (S.A.W.) on this point has an explanation when He says "Surely Allah is good and He likes goodness; He is pure and He likes purity." (Sahial-Tirmizi, v. 10, p. 240) As to environmental sanitation, the Prophet has also a warning to man and in His words "Surely Islam is pure, because He who is not pure can never enter the paradise.” (Kanzul Ummal, v. 9, 1979, pp. 277-78; Hadith nos. 26001, 26007)

The Holy Prophet (S.A.W.) was very much concerned about the environmental pollution and while He laid emphasis on purification, he prohibited people from spitting on the earth as it brings harmful effects on health. He was quite aware that such a habit was contradictory to human nature. The Holy Prophet has also warned against defecating under a fruit tree and urinating in stationery or flowing water and on the road so as to protect the environment from pollution and thereby to protect human health by purity. One can outline the importance of such an advice as to the danger of human waste products to our health vis-à-vis the environment especially the role which these contaminants of water play in spreading diseases to the human society through drinking, bathing and fruits which are watered by this water. ${ }^{\text {. }}$

In the light of the above, it can be inferred that there is a philosophy of Islamic Laws which is crucial in terms of Iman (belief) which propounds some rules of conduct to maintain environmental purity that in turn is a part of such obligation. The jurists of Islam have summarised the Islamic laws and analysed them in a simple formula that is "attracting to the best interest (Masalih) and repelling evil (corruption or Mafasid)." These two elements of Islamic laws prescribe impurity of something and the prohibition of such a thing in order to understand the value and worthiness of the Islamic philosophycum-rules and their exaltation against evil which would otherwise damage the balance and health of the earth. So, far an attempt has been made for the formulation of Islamic ecological ethics which delineate broad parameters of the ethical philosophy of Islam. It may be pointed out that, the general metaphysics of ethics in this religion offer not only extraordinary value-based paradigm indicating signs of environmental values but also a caution for the moral potentialities of the natural condition of man essential to the Quranic world view. It has been observed that, Islamic view is very different. However, the whole matter constitutes a scope for the self-realisation of the spirit. In addition to the above mentioned statement and warnings, the Prophet (S.A.W.) very beautifully puts it, "The whole of this earth is a mosque." (Iqbal, 1971, pp. 124f) To know and understand its importance it involves a kind of divine service which in Islam stands for Ibadat (prayer). In fact Muslim theologians think nature does not have any meaning without its reference to God; without divine purpose it simply becomes non-existent. (Ibid., p. 70) This is important because as the Quran says that, the man was created with the very idea of making him the Khalifah, that is, vice-regent of Allah on the earth. Allah disclosed his design to His angels that He was creating man to make him the viceregent and this conviction of man as vice-regent figures throughout the Quranic account of the creation of man and is inseparable from his creaturehood. ${ }^{\text {ii }}$ The role of man as 
Khalifah has been described in a large number of verses of the Quran. (Suras: 2:30; 6:165; 7:69, 74; 10:14, 73; 27:62; 36:39; 38:26) The obligation as a Khalifa in this earth has been clarified in the Quran when it mentions that, "God has made subject to man the Sun, the Moon, the stars, the day and the night, sea, all that is in the Heaven and on earth.” (Suras: 14:32, 33; 16:12, 14; 22:65; 31:20; 45:12, 13; 67:15) Man is thus a Lord or a Guardian over these things on the earth and his responsibility is lying with pleasing the Almighty.

We have already seen how there is an inseparable link between man and nature in the light of Islamic theology particularly in the Quran itself-Islamic revelation in a book which is considered a source of knowledge, certainty and judgement revealed through evolution and history. Nature visà-vis environment, as has been stated by some (Sardar, 1984, p. 161) to be "amenable to the discriminatory judgement of divine will and man, the instrument of divine purpose, has a mandate and responsibility to treat nature as a trust." Such a study offers an opinion from Islamic perspective that the debasement of environment by man leads to destruction of the human society which in other ways amount to revolt against the Almighty Allah. As to the plant environment the Quran has again cautioned by saying "It is He who sends down rain from the sky; from it you drink and out of it (grows) the vegetation on which you feed your cattle"; "with it He produces for you corn, olives, date-palms, grapes and every kind of fruit; variety in this is a sign for those who give thought." (Sura An- Nahl 16:10; Pickthall, pp.250f) Here is a clear indication of a serious caution on behalf of the Almighty to 'give thought' about the blessings of the Almighty Allah given to nature and the advantages offered to human society for survival. There is logic to environmental balance and the well-being of mankind. The Islamic message in these quotations of the Quran encourages the act of farming and planting trees so as to preserve the environmental sanctity of the society. In other words, it shows that, Islam regards the act of planting trees and preserving the earth as an act of worship and charity thereby conforms on the doer as an act of companionship of man and animals with the plants. The Almighty has even made it clear when it is written in the Quran "He brought you forth from the earth and made you husband (i.e. dwell) on it." (Sura Hud 11:61; Pickthall, p.211) The Prophet Muhammed (S.A.W.) has also narrated this obligation and prizes from different perspectives while calling it as a charity (Sadaqa). This Sadaqa may be a great benefit to the community as a whole.

'The Holy Quran' has logically discussed the issue of crime and aggression against life; condemned the destroyer of the animals', plants' and man's environment and rather turn such an aggression against humanity. Concerning this the 'Holy Quran' says "When he turns his back, his aim everywhere is to spread mischief through the earth and destroys the crops and the cattle; and Allah loves not mischief.” (Sura Al Baqarah 2:205; Pickthall, p. 32) In this verse the Holy Quran brings to light the offence of destruction of plants and animals violating the law in the earth and treats it as an aggression the life system and all the more to be erased as an evil. One can see in this statement how the Islamic Law and its ideologies correspond with the natural laws and balance to be maintained in the system of life. Crisis of humanity and in the environmental system have now become a universal concern but despite precautions natural laws are broken and the result is found in many dislocations. The distribution of water, mountains and forests and the nature of weather, climate and earth and the ratio of gases, light rays work under a wellequipped system. It ensures the welfare of the surroundings. But when men, due to ignorance or egoism and destructive 
activities, interrupt and enter the ecology, they cause a great damage to this very system. Men forget the destructive side of imbalance of the nature. The simple reason may be that the elements of nature are not merely productive resources but are also stimuli for any creative quest. If this 'creative quest' is lost by any means, it entails the destruction of whole mankind.

The harmony of knowledge and values which seems to be the ultimate aim of most of the religions, let alone Islam, can only be attained by the balance of a value system. Needless to say, to work for the establishment of the 'Kingdom of God' in this world is supposed to be the goal of Muslim morality which means hope for eternal bliss in the life here after is the essence of Islamic faith. This faith is connected with some obligation to be maintained by every Muslim (vis-à-vis all humans as a whole) and he or she performs it by divine service Ibadat. If this earth is a mosque, the whole universe may be taken as the 'Book of Revelation' full of signs (ayat) and to follow them is to honour the 'Divine Will'. The path of ecological justice according to Islamic law is paved with the ethical restraints of moderation. Here lies the remedy of the imminent environmental disaster.

Today the whole world is concerned with the ways to respond to the realities of nuclear weapons, bio-terrorism- a more complicated problem leading to bio-blunders which unleash new pathogens. (Wenger, 2008) Along with bioterrorism there is a great anxiety over the ill-effects of climatic change on the human civilisation. This problem had also drawn the attention of Kofi Annan, Former UN Secretary General, and in his address (Nairobi, $15^{\text {th }}$ November, 2006) pointed out "Climate change is not just an environmental issue, it is an allencompassing threat...” , i.e. threat to health, effect on food supply, human life as well as peace and security. (Barnett,
2007, pp. 1361-75) It is a fact that, man was created from the earth and he grows by way of it, and the plants and all other natural beings grow from it, that water is fundamental to life and the Almighty has colonized man in this world that is $\mathrm{He}$ has entrusted him by using His natural resources and its benefits-environmental balance. This is to understand the power of the Almighty and His blessings to him. Man is supposed to understand the 'Divine Will' and the inter-related units as well as the purpose of creation. Man should know that the Almighty's actions are on purpose and that all His activities are built on wisdom. All these benefits return not to the Almighty because He stands not in need of anything from His creations, rather it returns to them through the acquisition of Paradise. Unfortunately, humans have negated the mandate which needs to be followed by them under any circumstance, but since the matter is otherwise, they have virtually invited crisis not only in their lives but in the Nature as well. In fact, during the time of the Holy Prophet (about 1500 years back) and in the period when the Quran was compiled the environmental crisis was not so acute as it is today but there were warnings in the Quran as well as by the Prophet, as stated above, to take care about environment and climate as a whole for the sake of the existence of life in this earth. This is perhaps on this judgement, one may recall the challenging declaration of the Almighty Allah when He communicated His message through Prophet Muhammed (S.A.W.), "Say have ye thought, if all your water were to disappear in the earth who then could bring you gushing water.” (Sura Al-Mulk 67:30; Pickthall, p. 576) The concepts, models or theories emanating from such warnings and precautions are always worthy of analytical examination and realistic understanding as to the advices enshrined in the Quran and the Hadith. 


\section{References}

1. Abu Dawood, Sulaiman bin Ash'ath. (2008). Sunan Abu Dawood. Riyad, KSA: Darussalam Publishers \& Distributors.

2. Al Faruki, Ismail R. (1979). On the Metaphysics of Ethics in Islam Listening. Journal of Culture and Religion, 14(1).

3. Barnett, J. (2007). The Geopolitics of Climate Change. Geography Compass, 1(6)

4. Iqbal, Mohammed. (1971). Reconstruction of Religious Thought in Islam. Reprint ed., Lahore.

5. Jawziyya, Ibn Qaiyyum. (1983). Al- Amthal fi al- Quran al Karim, Beirut: Dar Al Maarifa.

6. Kulayni. (2014). Kitab-al-Kafi. Seattle, WA: CreateSpace Independent Publishing.

7. Mutaqi. (1979). Kanzul Ummal (in Hindi). Beirut: Al- Risala Foundation.

8. Pickthall, Marmaduke. (Trans.) (1996). The Meaning of the Glorious Koran. Later printing ed., Chicago, IL: Kazi Publications, Inc.

9. Sardar, Ziauddin. (1984). The Touch of Midas - Science, Values and Environment in Islam and the West. Manchester: Manchester University Press.

10. Wenger, Andreas and Reto Wollenmann (eds.) (2008). Bioterrorism - Confronting a Complex Threat. New Delhi: Viva Books Private, Ltd.

\footnotetext{
i Incidentally it is reported from a source i.e. Imam al- Sadiq (a.s.), one of the Sahaba (follower), that Prophet Mohammed (S.A.W.) used to prohibit defecation on the edge of a well, river or under a fruit tree. (For details see Wasail al-Shi'a by Hurr Amili, vol.1, The Book of Tehrah, p.228. In the same source it is noted that the Holy Prophet also gives caution not to urinate in stationery water, Hurr Amili, op. cit, p.241).
}

\footnotetext{
ii Surah Al- Baqarah 2:30: "And when thy Lord said unto the angels: Lo! I am about to place a viceroy (i.e. vice- regent) in the earth, they said: Wilt thou place therein one who will do harm therein and will shed blood, while we hymn Thy praise and sanctify Thee? He said: Surely I know that which ye know not." (Pickthall, p .9)
} 